\title{
Abortion Categories and Characteristics of Acarpous Crape Myrtle Floral Organs
}

\author{
Wei Zhou \\ College of Forestry, Central South University of Forestry and Technology, Changsha 410004, \\ P.R. China
}

Xiaoming Wang
Hunan Academy of Forestry, Changsha 410004, P.R. China

Jianhua Chen and Liangming Chen

College of Forestry, Central South University of Forestry and Technology, Changsha 410004, P.R. China

\author{
Zhongquan Qiao and Huijie Zeng \\ Hunan Academy of Forestry, Changsha 410004, P.R. China
}

\begin{abstract}
Additional Index words. anther, female abortion, Lagerstroemia indica, male sterility, ovule, scanning electron microscopy
ABstract. Lagerstroemia indica (crape myrtle) is a popular Chinese landscape plant with a long flowering period that contributes to its gorgeous flowers and high ornamental value, which motivate $L$. indica breeding. We found a wild acarpous individual of $L$. indica that did not bear seeds after flowering and had a significantly longer flowering period than fructiferous $L$. indica. This study identified differences in floral organ morphology, and stamen and pistil structure between fructiferous and acarpous $L$. indica through observation, paraffin sectioning, and scanning electron microscopy (SEM). The flowering time of each acarpous $L$. indica inflorescence lasts as long as 18 to 25 days. When a single flower withers, it falls from the pedicel without any fruit. The abortion in the floral organ of acarpous $L$. indica is characterized by sterile and undehisced anthers, pollen abortion, and deformed and irregularly arranged filament cells. Acarpous $L$. indica features short and loosely arranged papilla cells in the stigma, a flat style and narrow stylar canal, loosely arranged epidermal cells, and no obvious nuclei. No embryo sac cavity is found in acarpous $L$. indica ovules. In some nucelli, the egg apparatus structure can be observed indistinctly but without cell contour. In others, the egg apparatus structure is completely absent, and only flocculent tissue is observed. This study may provide a theoretical foundation for future studies on the molecular mechanisms of the mutations in acarpous $L$. indica.
\end{abstract}

Floral organs are important for the reproduction of angiosperms. They play an important role in the reproduction, development, and life cycles of plants. The morphology and function of male organs of male-sterile plants are abnormal, manifested mainly in deformed or degenerated stamens, thin and withered anthers, a lack of pollen, or hollow and nonviable pollen. Kaul (2012) proposed that the variants or phenomena underlying male sterility are mainly in structure and function, and include anamorphosis of the androecium, weak vascular bundle formation, abnormal anther wall development, and undehisced anthers. Similarly, during ovule development, any disruption results in immature and infertile ovules. The major features of aborted ovules include malformation or an absence of egg cells, synergid cells, or polar nuclei; the presence of only a developed integument; undeveloped nucellus tissue; and no mature embryo sac. Therefore, double fertilization does not result in the formation of the embryo and endosperm (Akhalkatsi et al., 1999; Casper and Wiens, 1981; Gao et al., 2017).

Lagerstroemia indica is native to Asia and is a deciduous shrub or small tree belonging to the family Lythraceae. It has a long history of cultivation and is an important landscape plant

Received for publication 5 June 2019. Accepted for publication 29 July 2019. This work was supported financially by the Changsha Science and Technology Planning Project (Kq1801026).

X.W. and J.C. are the corresponding authors. E-mail: wxm1964@163.com or cjh11135@sina.com. as a result of its gorgeous flowers and high ornamental value. It is widely grown in China, Japan, and North Korea, and has been introduced to some countries in Europe and the Americas for cultivation (Wang et al., 2014). In 2012, its wholesale value was $\$ 66$ million (U.S. Department of Agriculture, 2014). L. indica has been widely planted for city landscape greening, expressway greening, sand control, and slope protection. In addition, its plants can also be used in medicine, and flavors can be extracted from its flowers. There are $\approx 55$ species in the genus Lagerstroemia, of which 21 species are distributed in China. Currently, there are many cultivars of $L$. indica in China, most of which were selected based on natural variation in the species in the wild. Our research team accidentally came across an acarpous individual of L. indica in the wild in 2006 (Wang et al., 2014). Compared with normal L. indica, this $L$. indica bears no fruit after flowering. Its flowering period can last as long as 115 to $132 \mathrm{~d}$, according to 5-year observations by the current team, whereas that of normal L. indica lasts 60 to $80 \mathrm{~d}$ (Chen et al., 2012). It has high ornamental value and significant abortion of its floral organs.

The reproduction of $L$. indica has been investigated. Pacini and Bellani (1986) studied the structure and function of $L$. indica pollen. They found that L. indica had spherical pollen, with a textured surface and smooth polar faces. However, there are few studies on the reproductive biology of $L$. indica. The development of its pollen and ovules is poorly studied, and the reproductive characteristics of acarpous $L$. indica have not yet been reported. 
In this study, we examined the categories and characteristics of floral organ abortion in acarpous L. indica and compared differences between fructiferous $L$. indica and acarpous $L$. indica. The results of this study may provide a theoretical foundation for research on the molecular mechanisms of the seedless mutations in L. indica, as well as reproductive biology with regard to the mutations.

\section{Materials and Methods}

\section{Materials}

The acarpous $L$. indica cultivar 'Xiang Yun' and fructiferous $L$. indica in this study were grown in Hunan Botanical Garden, Changsha, China (lat. $28^{\circ} 10^{\prime} \mathrm{N}$, long. $113^{\circ} 03^{\prime} \mathrm{E}$ ). The botanical garden is in a typical mid-subtropical monsoon humid climate zone with an annual average temperature of $19.8^{\circ} \mathrm{C}$, an annual accumulated temperature of $5586{ }^{\circ} \mathrm{C}$, an annual average frost-free period of 279 to $295 \mathrm{~d}$, a mean annual sunshine duration of $1873 \mathrm{~h}$, and an annual average precipitation of $1420 \mathrm{~mm}$. The soil is quaternary red clay with moderate fertility and a $\mathrm{pH}$ of $\approx 5.7$. Twenty flowers were collected in the full-blossom period in Aug. 2016, 2017, and 2018 from inflorescences of acarpous $L$. indica and fructiferous L. indica. The calyx and petals were removed from the flowers. The stamens and pistils were fixed in Carnoy's solution for $12 \mathrm{~h}$. Subsequently, they were vacuumed and transferred to a $70 \%$ alcohol solution and stored in a refrigerator at $4{ }^{\circ} \mathrm{C}$ for later use.

\section{Methods}

Direct observation. Inflorescences were taken from acarpous L. indica and fructiferous L. indica individuals. The whole inflorescence, floral buds, floral organs, fruit, and carpopodia were observed directly, and photos were taken. The floral organs of acarpous $L$. indica with variations were categorized, and the quantity of each category was recorded.

Paraffin Sectioning. Paraffin sectioning was performed according to Gao et al. (2015). After proper trimming, the fixed materials were dehydrated by various concentrations $(30 \%, 50 \%, 70 \%, 85 \%, 95 \%$, and $100 \%$ ) of alcohol, made transparent by xylene, and embedded after paraffin permeation. They were sliced using a rotary microtome (RM2235; Leica, Heidelberg, Germany) to a thickness of $8 \mu \mathrm{m}$. Later, they were bonded, deparaffinized, rehydrated, mordanted with $4 \%$ ferric ammonium sulfate for $3 \mathrm{~h}$, and dyed with $0.8 \%$ Ehrlich's hematoxylin for $25 \mathrm{~min}$. Color separation was conducted with $2.0 \%$ ferric ammonium sulfate for $20 \mathrm{~min}$. Then, they were dehydrated, stained with $0.5 \%$ eosin, and permanently prepared with Canadian balsam. Finally, photographs were taken under an optical microscope (DM3000, Leica).

SEM. SEM was performed according to Gao et al. (2015). The pollen and anthers taken from the floral organ on the day of anthesis were used as samples and fixed with $2.5 \%$ glutaraldehyde fixative (prepared with $0.2 \mathrm{~mol} \cdot \mathrm{L}^{-1}$ phosphate buffer) for $2 \mathrm{~h}$, washed with phosphate buffer $\left(0.2 \mathrm{~mol} \cdot \mathrm{L}^{-1}\right)$, and fixed with $1 \%$ osmic acid fixative (prepared with 0.2 $\mathrm{mol} \cdot \mathrm{L}^{-1}$ phosphate buffer) for $4 \mathrm{~h}$. After that, the samples were washed with phosphate buffer $\left(0.2 \mathrm{~mol} \cdot \mathrm{L}^{-1}\right)$ and dehydrated in an ethanol gradient. After the transition to tert-butyl alcohol, freeze-drying was carried out. The treated material was placed on the sample stage and then placed in ionsputtering equipment for gold plating for $20 \mathrm{~min}$. The material was observed and photographed using SEM (JSM6380; JEOL, Tokyo, Japan).
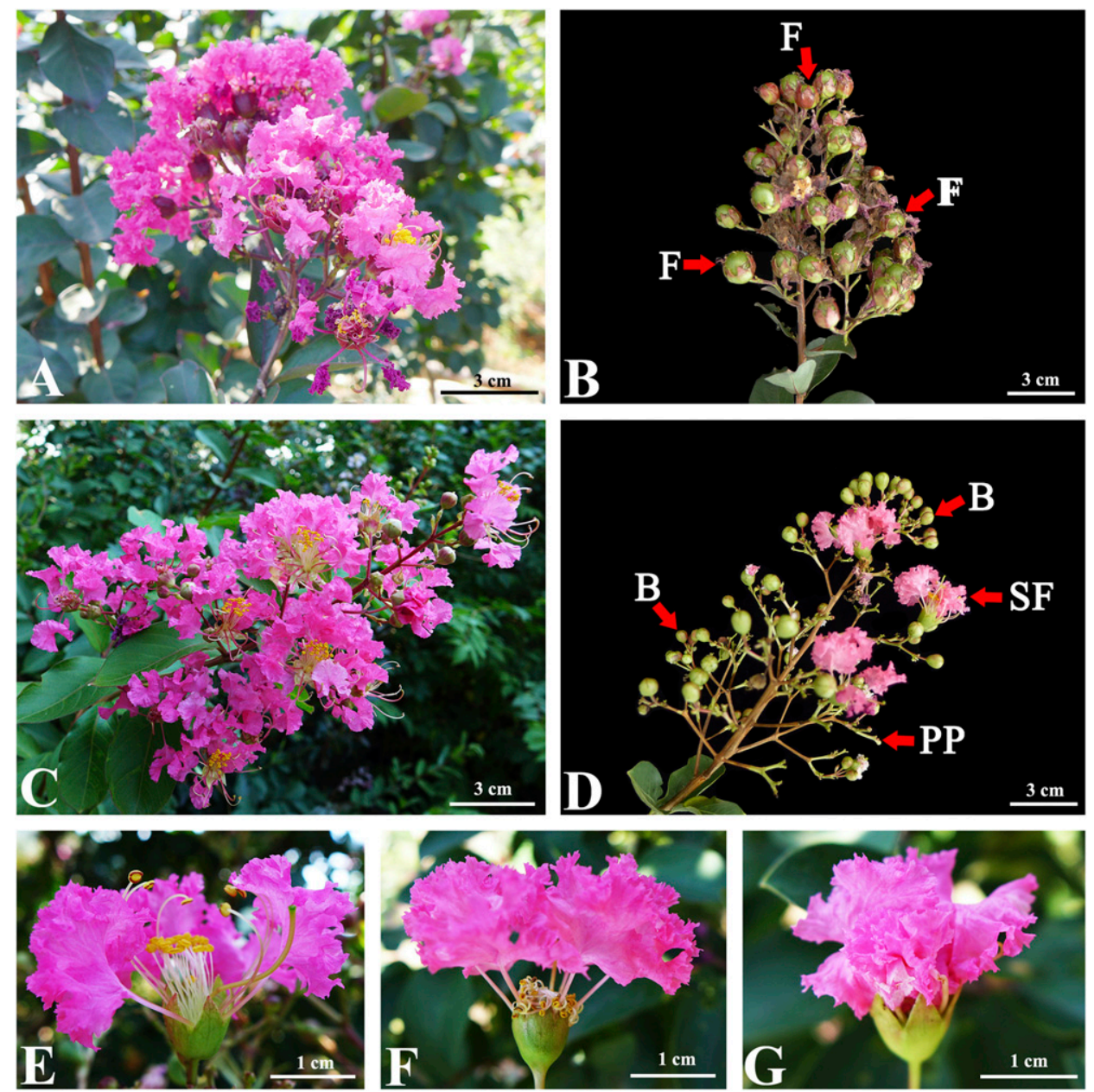

Fig. 1. Characteristics of floral organs of both fructiferous Lagerstroemia indica and acarpous L. indica. (A) An inflorescence of fructiferous $L$. indica, with all flowers blooming almost simultaneously. (B) Fruiting of one inflorescence of fructiferous L. indica. (C) Flowering state of one inflorescence of acarpous $L$. indica. (D) An inflorescence of acarpous $L$. indica with persistent pedicels (PPs) after the flower has withered and single flowers (SFs) in blossoms and buds (Bs) at different developmental stages. (E) Category A floral organs of acarpous $L$. indica, similar in shape to those of fructiferous $L$. indica. (F) Category B floral organs of acarpous $L$. indica, with curly filaments, brownish yellow anthers, and invisible styles. (G) Category C floral organs of acarpous $L$. indica, with only the calyx and clustered petals visible. F, fruit. 


\section{Results}

DifFERENCES IN THE MORPHOLOGY OF FLORAL ORGANS. Based on the observations over 3 consecutive years (2016-18), the flowering period for each flower in each inflorescence of fructiferous $L$. indica is quite uniform, with all flowers blooming at almost the same time. The flowering of each inflorescence lasts 6 to $10 \mathrm{~d}$. Individual flowers wither and fall at almost the same time, and individual fruit mature at almost the same time (Fig. 1A and B). There is a noticeable difference in the flowering period between acarpous $L$. indica and fructiferous $L$. indica. The flowering period of each inflorescence of acarpous $L$. indica is 18 to $25 \mathrm{~d}$. Single flowers within an inflorescence do not bloom all at once. Instead, only some flowers bloom at the same time. During the blooming period, flower buds mature continuously and bloom continuously. Therefore, the entire inflorescence has a longer flowering period. After a single flower withers and falls from the pedicel, no fruit is visible (Fig. $1 C$ and D). Acarpous $L$. indica flowers are rosy. Three categories are identifiable when observing the morphology of the floral organ of acarpous L. indica. In category A, there is no difference in floral organs between acarpous $L$. indica and fructiferous L. indica. The corolla diameter is 3 to $4 \mathrm{~cm}$. The flowers consist of six crepe-like petals 12 to $20 \mathrm{~mm}$ long, six triangular and upright calyx lobes, and 36 to 46 upright stamens with visible anthers. Six exterior stamens, with filaments that are longer than those of other stamens, grow on the calyx, forming six strong stamens. The style, which is slightly curved and taller than the androecium, protrudes outside the androecium and is visible (Fig. 1E). In category $B$, the corolla of the floral organ is 2 to 3 $\mathrm{cm}$ in diameter and the petals are slightly less open than those of category A. The filaments are all curved and spiral. The anthers are brownish yellow and prostrate over the calyx, and the style is not visible (Fig. 1F). In category C, the corolla of the floral organ is 1 to $2 \mathrm{~cm}$ in diameter. Only petals are visibly clustered in the calyx, with no externally visible stamens or styles (Fig. 1G). The pedicels of the three variant categories are 8 to $15 \mathrm{~mm}$ long and are covered evenly with fine hairs. The ovary is buried in the androecium of acarpous $L$. indica. The three variant categories of floral organs of acarpous $L$. indica
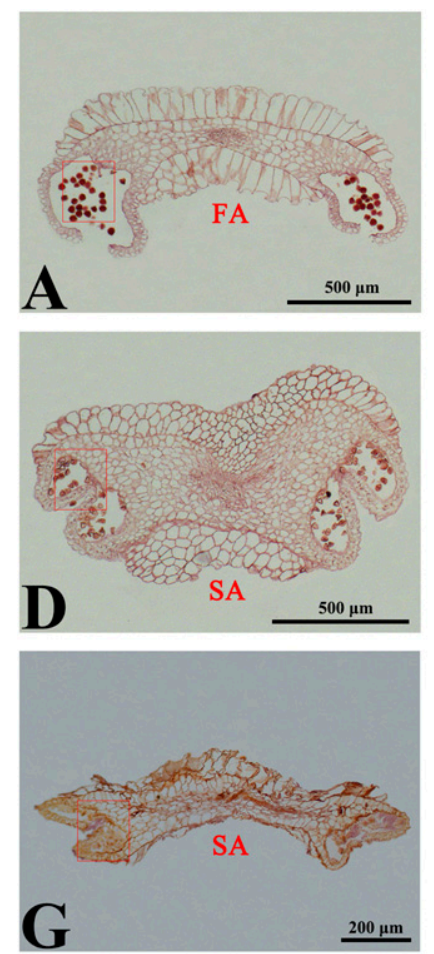

together form 7 - to 20 -cm-long terminal panicles. The ratio of the three variant categories of floral organs in each inflorescence is $7 \mathrm{~A}: 2 \mathrm{~B}: 1 \mathrm{C}$.

DifferenCES IN STAMEN STRUCTURE. Anthers of $L$. indica are already mature at anthesis. The anther of fructiferous $L$. indica is tubular, and its connective tissue, consisting of four to six layers of cells, is long and narrow. The vascular bundle is located centrally and there is a layer of loose, elongated cells on the upper and lower connective tissue. The two dehiscent anther cells are connected at both ends of the anther. After the dehiscence of the anther, only the epidermis and the ribbon-like thickened inner wall of the anther cell are left behind (Fig. 2A). The cells at the junction of two pollen sacs have dehydrated and
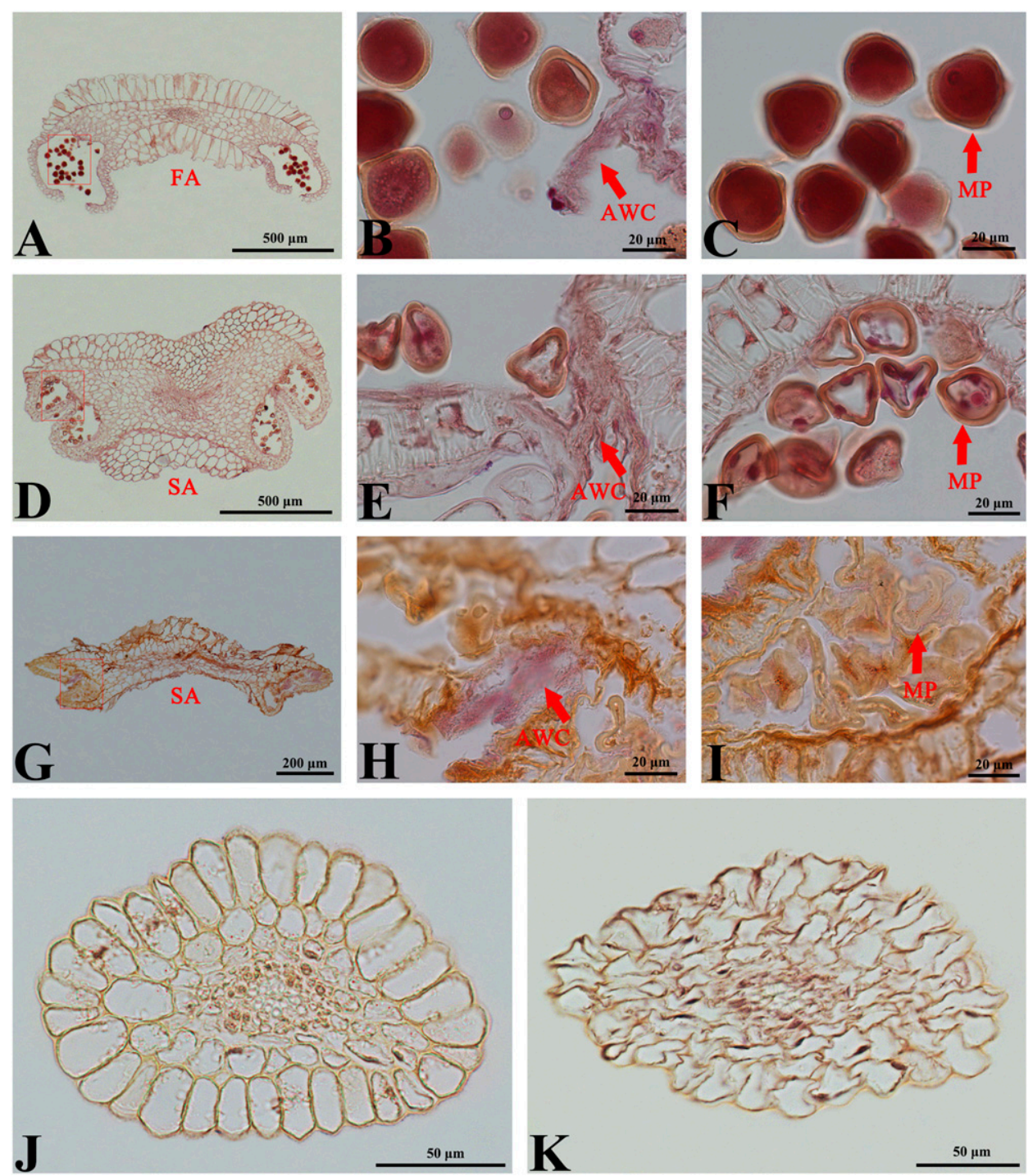

Fig. 2. Characteristics of the anther and filament structure of fructiferous Lagerstroemia indica and acarpous $L$. indica. (A) Mature fertile anthers (FAs) of fructiferous L. indica on the day of flowering. (B) Dehydrated anther wall cells (AWCs) and dehisced pollen sac [(A) enlarged]. (C) Mature two-celled pollen grains filled with inclusions [(A) enlarged]. (D) Sterile anthers (SAs) of category A acarpous L. indica. (E) Category A sterile anthers in which anther cells are unable to dehisce [(D) enlarged]. (F) Sterile pollen of category A, with no inclusions in the dry and deformed pollen grains [(D) enlarged]. (G) Sterile anthers in categories B and C of acarpous $L$. indica. $(\mathbf{H})$ Anther cells of sterile anthers unable to dehisce $[(\mathbf{G})$ enlarged]. (I) Sterile pollen in the anther cells of categories B and C, where pollen grains are not fully developed and are severely deformed. (J) Filaments of fructiferous $L$. indica, with visible epidermal cells, parenchyma cells, and vascular bundles. (K) Filaments of acarpous $L$. indica, with deformed and irregularly arranged cells. MP, mature pollen. 
degenerated (Fig. 2B). The mature pollen grains in the anther have developed into two-celled pollen. The pollen grains filled with inclusions are of a dark color (Fig. 2C). The anthers of category A acarpous $L$. indica variant floral organs are relatively thick. The connective tissue is composed of 12 to 16 layers of cells. The upper and lower ends of the connective tissue comprise two to four layers of cells. The vascular bundles are irregular (Fig. 2D). The pollen sacs at both ends of the anther do not dehisce. The cells at the junction are connected to the anther wall of the two anther cells. There are anomalies in tissue dehydration during anther dehiscence (Fig. 2E). The pollen grains are dry, shrunken, and without inclusions (Fig. 2F). In categories B and C "misdeveloped" floral organs of acarpous $L$. indica, the anthers are brownish yellow and dry, with an indistinct cell structure (Fig. 2G). The cells at the junction of the two anther cells are short and deformed, and the two adjacent anther cells are not connected (Fig. $2 \mathrm{H})$. The pollen grains are not fully developed and are severely deformed in the anther cell, with an indistinct structure (Fig. 2I).

Filament structure also differed between acarpous $L$. indica and fructiferous $L$. indica. The filament cells of fructiferous $L$. indica are distinct in structure, with the outermost layer being a layer of regularly arranged epidermal cells and the inner layer being parenchyma cells and vascular bundles (Fig. 2J). The filament cells of acarpous $L$. indica consist of irregularly arranged cells with indistinct structure and unidentifiable tissue structural features (Fig. 2K).

SEM shows that after anther dehiscence of fructiferous $L$. indica, pollen is released and densely scattered on the anther wall (Fig. 3A); no dehiscence was observed for the anther of acarpous L. indica (Fig. 3B). The removed pollen grains were studied. It was found that fructiferous $L$. indica has three germinal furrows, and its pollen grains are round, full, and well developed (Fig. 3C and E). The anthers of acarpous L. indica are dry, shrunken, and severely deformed. At the same level of magnification, the volume of the latter is obviously smaller than that of fructiferous L. indica (Fig. 3D and F).

DifFERENCES IN PISTIL STRUCTURE. The pistil of $L$. indica has a complete stigma, style, and ovary structure. The stigma surface of $L$. indica is dense with papilla cells, which are concentrated in the middle of the style and extend downward. Papilla cells of fructiferous $L$. indica are arranged in a regular pattern compared with those of acarpous $L$. indica. Papilla cells

of fructiferous $L$. indica are long with a thick cytoplasm, whereas those of acarpous L. indica are short, small, and loosely arranged (Fig. 4A and B).

A cross-sectional view reveals that the style of $L$. indica is a hollow structure. The style of fructiferous $L$. indica is nearly round, whereas that of acarpous $L$. indica is flat. The style consists of the outer epidermis, basic tissue, and inner epidermis of the stylar canal, which is the channel for the growth of the pollen tube. The inner epidermis of the stylar canal of fructiferous $L$. indica is composed of five to seven layers of compact and nearly round cells, forming six uniform protrusions. Cells of this layer are smaller and more compact than basic tissue cells. Under a light microscope, one can observe distinct nuclei, thick cytoplasm and characteristics of glandular cells, and the regular arrangement of basic tissue cells (Fig. 4C and $\mathrm{E}$ ). The stylar canal of acarpous $L$. indica is narrow, and the inner epidermal cells are loosely arranged, distributed sporad- 

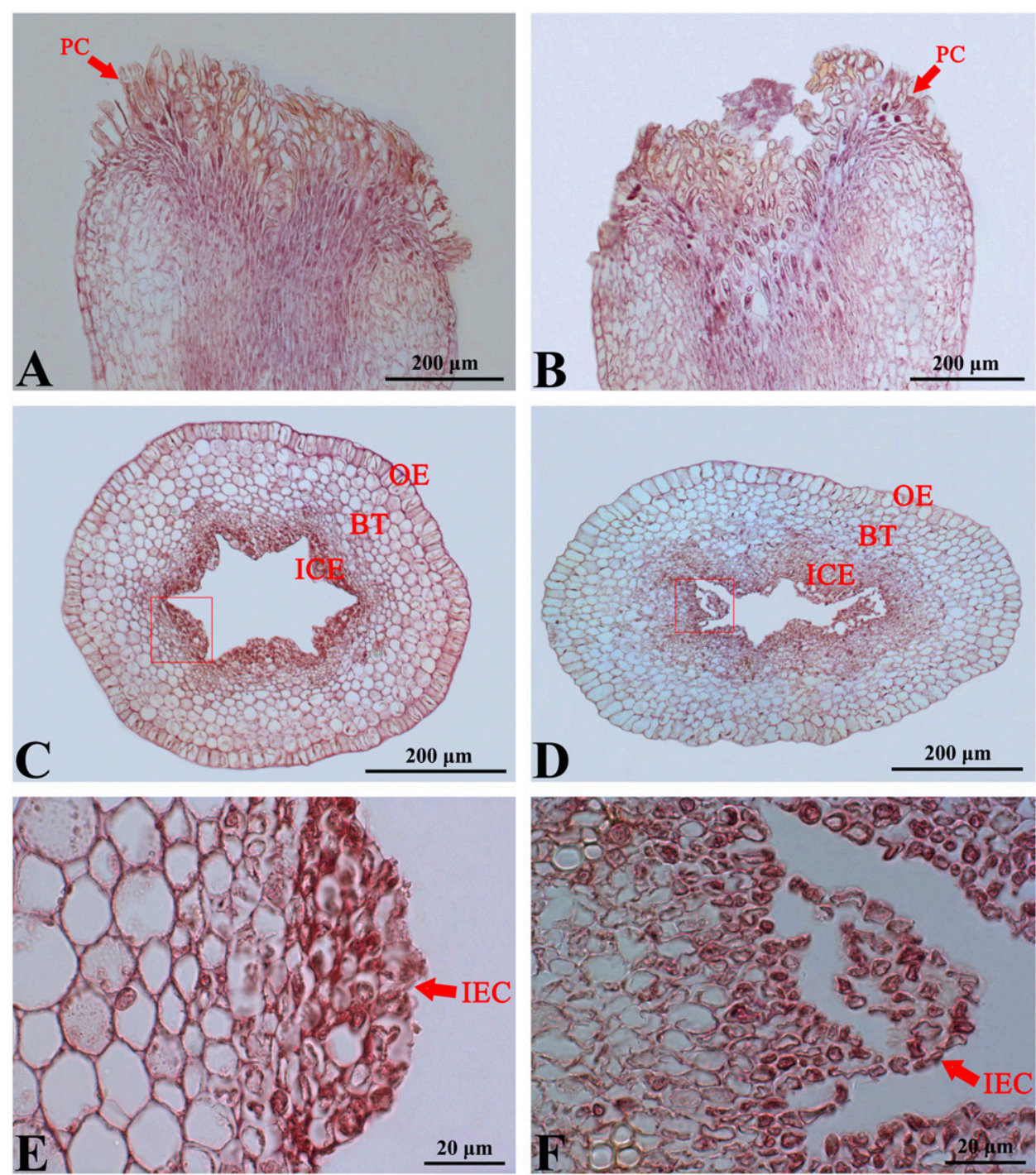

Fig. 4. Characteristics of the stigma and style of fructiferous Lagerstroemia indica and acarpous L. indica. (A) Fructiferous $L$. indica stigma, with papilla cells (PCs) that are long and regularly arranged, converging to form a stylar canal. (B) Acarpous L. indica stigma, with PCs that are short and loosely arranged. (C) Fructiferous $L$. indica style, which is hollow and nearly round, consisting of the outer epidermis (OE), basic tissue (BT), and inner epidermis of the stylar canal. (D) Flat style and narrow stylar canal of acarpous L. indica. (E) Small and compact inner epidermal cells (IECs) of the stylar canal of fructiferous $L$. indica and characteristics of glandular cells [the enlarged framed area in (C)]. (D) IECs of acarpous L. indica, loosely arranged with no obvious nucleus [the enlarged framed area in $(\mathbf{D})]$.

ically, and have large gaps between each other. There is no obvious nucleus, and basic tissue cells are irregularly shaped and disorderly arranged (Fig. 4D and F). L. indica has an axial placenta. According to anatomical observation of the ovary, there are five to eight locules per ovary, and the number of ovules in each ovary ranges from 115 to 143 . All ovules, which are connected to the placenta via short funicles in the ovary, are anatropous. Through observation by means of the paraffinsectioning method, it was found that in the ovary of fructiferous $L$. indica, an embryo sac cavity is formed as a result of the development of mature ovules, and the ovule has complete synergid cells, egg cells, and polar nuclei (or secondary nuclei) (Fig. 5A, B, E, and G). No well-developed ovules with embryo sac cavities were observed in the ovary of acarpous $L$. indica. All the ovules were aborted (Fig. 5C and D). Based on a large number of sectioning observations, the development and characteristics of aborted ovules of acarpous $L$. indica can be divided into two categories. In the first category, the egg apparatus structure is indistinctly visible in the nucellus of the aborted ovule, without a cell contour, similar to the characteristics of cells after degeneration. There is no gap in the embryo sac cavity (Fig. $5 \mathrm{H})$. In the second category, the egg apparatus structure is completely absent in the nucellus of the aborted ovule, consisting of flocculent tissue, and there is no embryo sac cavity (Fig. 5I).

\section{Discussion}

L. indica is an important landscape plant that has radiant, beautiful flowers and thus a high ornamental value. Although $L$. indica currently consists of a large variety of cultivars, most of the cultivars have a short flowering season, early fruiting, and a large number of fruit, which decrease their ornamental value greatly. The current team has long endeavored to contribute to the selection and breeding of excellent $L$. indica cultivars. By accident, we found an acarpous L. indica plant in the wild. Compared with fructiferous $L$. indica, this plant had a longer flowering season but did not set fruit after blossoms fell, which might decrease the consumption of nutrients and energy of the tree.

Sporogenetic male sterility is characterized by the normal development of stamens, but defects in microsporogenesis or microgametogenesis. These characteristics result in failed pollen production or the formation of abnormal, deformed pollen, leading to the total loss or functional loss of pollen (Kaul, 2012), particularly the untimely degradation of the callose surrounding tetraspores and disruption of meiosis and microspore and/or pollen development (Budar and Pelletier, 2001; Dell, 1981; Sanders et al., 1999). In addition, maldevelopment or degeneration of the vascular bundles in stamens can cause substance metabolism disorders during the development of floral organs, thereby leading to pollen abortion (Chen and Liu, 2014). In this study, abnormalities in anthers were observed in all three categories of floral organs: Pollen sacs were unable to dehisce, pollen grains were hollow and dry without inclusions, and abnormalities in the vascular bundle structure occurred. During the development of anthers, abnormal transport and metabolism of nutrients in tissue cells have a far-reaching impact on pollen abortion. The inner wall of the anther cell usually consists of one layer and has 


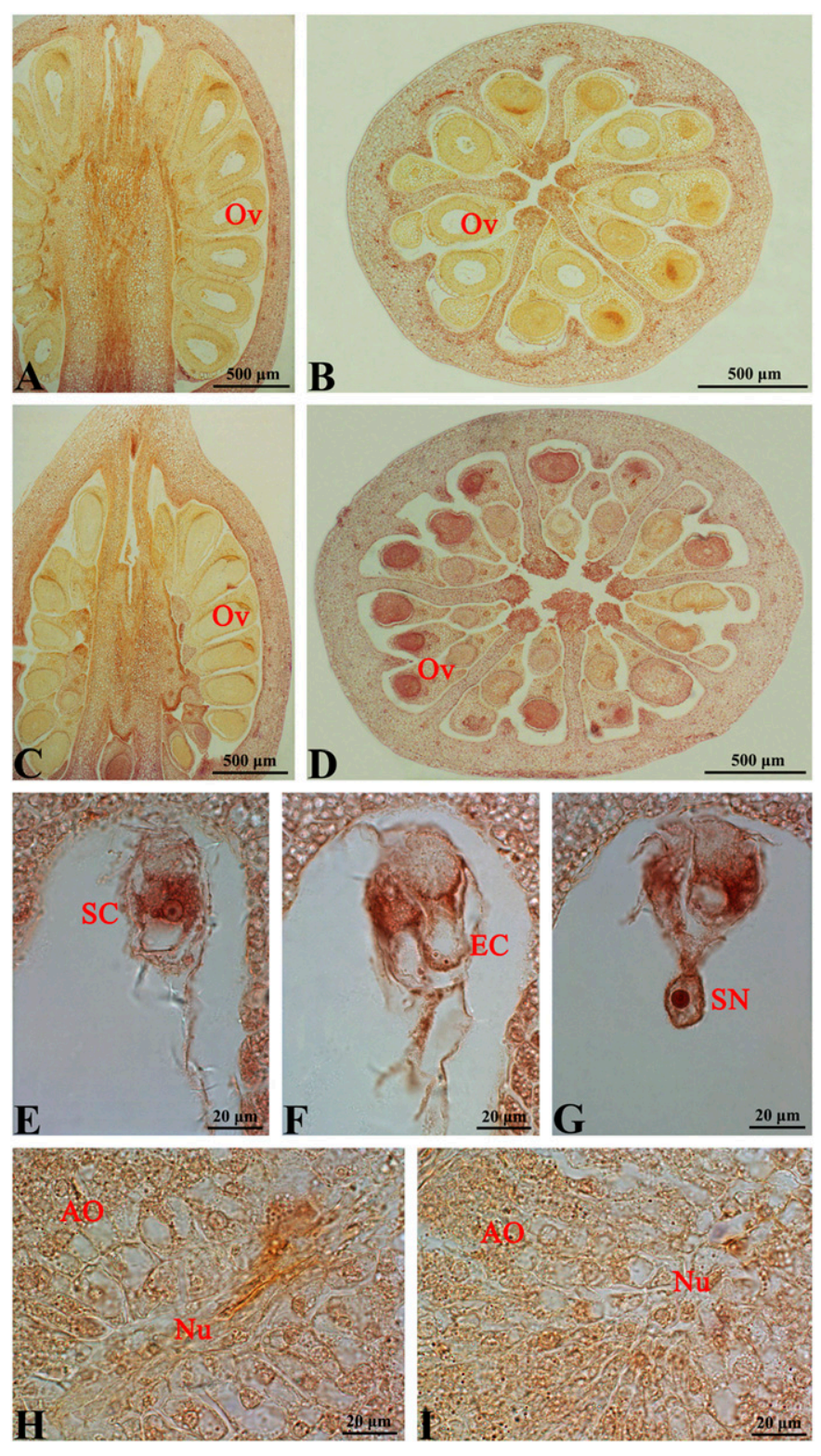

Fig. 5. Characteristics of the ovary and ovule $(\mathrm{Ov})$ of fructiferous Lagerstroemia indica and acarpous L. indica. (A) Longitudinal sectional view of a fructiferous $L$. indica ovary, showing a row of ovules in a locule and an embryo sac (ES) cavity in the ovule. (B) Cross-sectional view of a fructiferous L. indica ovary (near the base of the style). (C) Longitudinal sectional view of an acarpous $L$. indica ovary, showing a row of ovules in a locule and no embryo sac cavity in the ovule. (D) Cross-sectional view of an acarpous $L$. indica ovary (near the base of the style). (E) Synergid cells (SCs) in the ovule of fructiferous L. indica. (F) Egg cells in the ovule of fructiferous $L$. indica. (G) Secondary nucleus (SN) in the ovule of fructiferous $L$. indica. (H) First category: aborted ovules (Ao) of acarpous $L$. indica, where the egg apparatus is indistinctly visible in the nucellus $(\mathrm{Nu})$, yet no cell contour can be seen. (I) Second category: aborted ovules of acarpous $L$. indica, where the egg apparatus structure, consisting of mainly flocculent tissues, is completely absent in the nucellus.

a large vacuole. A few plants have two layers. This layer of cells is immediately below the epidermis and stores starch grains and other nutrients during the initial stage (Feng and Dickinson, 2010). When anthers are mature, the anther endothecium cells are highly developed. The cells expand radially, and the stored material disappears. The inner wall is thickened in the shape of a band or fiber except for the side that is in contact with the epidermis. The structure of the inner wall of the anther cell is abnormal, probably preventing anthers from dehiscing normally and releasing pollen (Kaul, 2012). In our study, it was observed that the anthers of acarpous $L$. indica were unable to dehisce normally, which was related to the abnormality of the outermost cell of the inner wall of the anther cell to some extent.

Observations in our study revealed that the papilla cells on the stigma of fructiferous $L$. indica were elongated and regularly arranged on the surface, whereas the papilla cells on the stigma of acarpous L. indica were short and loosely arranged. Normally, differential structures of stigmatic cells are associated with the success of pollen reception, such as in Callaeum psilophyllum (Aliscioni et al., 2018). Therefore, whether the difference in papillary cell length in $L$. indica is associated with pollen reception, which further influences pollination and breeding, remains to be explored in the future. Furthermore, comparisons between the normal and aborted ovules of $L$. indica showed that maldevelopment and degeneration occurred in most ovules in a large number of sterile floral organs. In some plant species with female abortion, such as Citrus sinensis (Bender et al., 2017), embryo sacs degenerate before fertilization, although full development proceeds. The growth characteristics of fertile ovules in numerous plant species have been reported (Gao et al., 2017; Reiser and Fischer, 1993; Shi and Yang, 2011). In most of these plants, as in fructiferous $L$. indica, fertile ovules with a blastocyst cavity are formed in the ovary and synergids, and ova and secondary nuclei with normal development can be observed. In contrast, observations of ovules in the ovary of acarpous $L$. indica did not reveal that the embryo sac cavity formed. These aborted ovules existed on the day of flowering, instead of developing during the development process after fertilization. The features regarding ovule abortion of acarpous $L$. indica were similar to those of Camellia oleifera (Gao et al., 2017) and Medicago sativa (Wang et al., 2011). From an embryological point of view, plant ovules undergo a long process from the beginning of growth and development to seed maturation. Abortion may occur at any stage-from the occurrence of megaspore mother cells and megaspore mother cell meiosis through the formation of female gametophytes until even the late development of fertilized ovules ( $\mathrm{Hu}, 2005,2016)$. The two categories of ovule abortion of acarpous $L$. indica in general are caused by the failure of normal development of nucellar tissue, although the categories present different characteristics. To the best of our knowledge, abortion before embryo sac maturation in $L$. indica has not been reported previously.

\section{Literature Cited}

Akhalkatsi, M., M. Pfauth, and C.L. Calvin. 1999. Structural aspects of ovule and seed development and nonrandom abortion in Melilotus officinalis (Fabaceae). Protoplasma 208:211-223.

Aliscioni, S.S., M. Gotelli, and J.P. Torretta. 2018. Structure of the stigma and style of Callaeum psilophyllum (Malpighiaceae) and its relation with potential pollinators. Protoplasma 255:1433-1442.

Bender, R.J., R.P. Santos, D. Guerra, and S.F. Schwarz. 2017. 'URS Campestre' seedless orange: A new mutant with female sterility. Sci. Agr. 74:371-377.

Budar, F. and G. Pelletier. 2001. Male sterility in plants: Occurrence, determinism, significance and use. C. R. Acad. Sci. III 324:543-550.

Casper, B.B. and D. Wiens. 1981. Fixed rates of random ovule abortion in Cryptantha flava (Boraginaceae) and its possible relation to seed dispersal. Ecology 62:866-869. 
Chen, F.J., B. Xu, and Y.H. Xie. 2012. Phenology and visual valuable analyze of Lagerstroemia indica. Northern Hort. 14:64-67.

Chen, L.T. and Y.G. Liu. 2014. Male sterility and fertility restoration in crops. Annu. Rev. Plant Biol. 65:579-606.

Dell, B. 1981. Male sterility and anther wall structure in copperdeficient plants. Ann. Bot. 48:599-608.

Feng, X.Q. and H.G. Dickinson. 2010. Tapetal cell fate, lineage and proliferation in the Arabidopsis anther. Development 137:24092416.

Gao, C., R. Yang, and D.Y. Yuan. 2017. Characteristics of developmental differences between fertile and aborted ovules in Camellia oleifera. J. Amer. Soc. Hort. Sci. 142:330-336.

Gao, C., D.Y. Yuan, Y. Yang, B.F. Wang, D.M. Liu, and F. Zou. 2015. Pollen tube growth and double fertilization in Camellia oleifera. J. Amer. Soc. Hort. Sci. 140:12-18.

$\mathrm{Hu}$, S.Y. 2005. Reproductive biology of angiosperms. China Higher Education Press, Beijing, China.

$\mathrm{Hu}$, S.Y. 2016. The structure of plants-An atlas. China Higher Education Press, Beijing, China.

Kaul, M.L.H. 2012. Male sterility in higher plants. Springer-Verlag, Berlin/Heidelberg, Germany.
Pacini, E. and L.M. Bellani. 1986. Lagerstroemia indica L. pollen: Form and function, p. 347-357. In: S. Blackmore and I.K. Ferguson (eds.). Pollen and spores: Form and function. Linnean Soc. Symp. Ser. 12. Academic Press, London, UK.

Reiser, L. and R.L. Fischer. 1993. The ovule and the embryo sac. Plant Cell 5:1291.

Sanders, P.M., A.Q. Bui, K. Weterings, K.N. McIntire, Y.C. Hsu, P.Y. Lee, M.T. Truong, T.P. Beals, and R.B. Goldberg. 1999. Anther developmental defects in Arabidopsis thaliana male-sterile mutants. Sex. Plant Reprod. 11:297-322.

Shi, D.Q. and W.C. Yang. 2011. Ovule development in Arabidopsis: Progress and challenge. Curr. Opin. Plant Biol. 14:74-80.

U.S. Department of Agriculture. 2014. 2012 Census of horticultural specialties. 16 May 2016. <https://www.agcensus.usda.gov/Publications/ 2012/Online_Resources/Census_of_Horticulture_Specialties/>.

Wang, X., X. Li, J. Zhang, G. Feng, S. Zhang, L. Huang, R. Zhuo, and L. Jin. 2011. Characterization of nine alfalfa varieties for differences in ovule numbers and ovule sterility. Austral. J. Crop Sci. 5:447-452.

Wang, X.M., J.J. Chen, H.J. Zeng, Z.Q. Qiao, Y.X. Li, N. Cai, and X.Y. Wang. 2014. Lagerstroemia indica 'Xiangyun', a seedless crape myrtle. HortScience 49:1590-1592. 